\title{
Correction to: The burden of war-injury in the Palestinian health care sector in Gaza Strip
}

\author{
Marwan Mosleh ${ }^{1 *}$, Koustuv Dalal ${ }^{2,3}$, Yousef Aljeesh $^{4}$ and Leif Svanström ${ }^{5}$
}

\section{Correction}

In the original publication of this article [1] the background section contained an inaccurate mention of the amount of civilian deaths in the 2014 Gaza war. In this correction article the incorrect and correct information are published for clarification.

Incorrect:

- More recently, in the 2014 Gaza war, more than 2200 civilians were killed [12]

Corrected:

- More recently, in the 2014 Gaza War, according to a report from the Palestinian Health Information Center [12], there were 2200 deaths. The majority were civilians

Further information related to the report from Palestinian Health Information Center can be accessed from the original publication.

\footnotetext{
Author details

${ }^{1}$ Department of Health Sciences, Mid Sweden University, Sundsvall, Sweden. ${ }^{2}$ School of Health Sciences, Örebro University, Örebro, Sweden. ${ }^{3}$ Higher School of Public Health, Al-Farabi Kazakh National University, Almaty, Kazakhstan. ${ }^{4}$ Islamic University of Gaza, Gaza Strip, Palestine. ${ }^{5}$ Professor (Emiratus), Karolinska Institutet, Stockholm, Sweden.
}

Received: 9 August 2018 Accepted: 9 August 2018

Published online: 13 August 2018

\section{Reference}

1. Mosleh M, Dalal K, Aljeesh Y, Svanström L. The burden of war-injury in the Palestinian health care sector in Gaza Strip. BMC Int Health Hum Rights. 2018;18:28. https://doi.org/10.1186/s12914-018-0165-3.

\footnotetext{
* Correspondence: marwanmoon@hotmail.com

${ }^{1}$ Department of Health Sciences, Mid Sweden University, Sundsvall, Sweden

Full list of author information is available at the end of the article
}

(c) The Author(s). 2018 Open Access This article is distributed under the terms of the Creative Commons Attribution 4.0 International License (http://creativecommons.org/licenses/by/4.0/), which permits unrestricted use, distribution, and reproduction in any medium, provided you give appropriate credit to the original author(s) and the source, provide a link to the Creative Commons license, and indicate if changes were made. The Creative Commons Public Domain Dedication waiver (http://creativecommons.org/publicdomain/zero/1.0/) applies to the data made available in this article, unless otherwise stated. 